\title{
KLAUSULA BAKU DALAM PERJANJIAN KREDIT BANK PERKREDITAN RAKYAT
}

\author{
M. Arif Maulana, Diah Sulistyani RS, Zaenal Arifin, Soegianto Soegianto \\ Magister Hukum Universitas Semarang, Semarang \\ advarifmaulana@gmail.com
}

\begin{abstract}
Abstrak
Penelitian ini bertujuan untuk mengetahui proses dan prosedur penyusunan perjanjian kredit yang dilakukan oleh Bank Perkreditan Rakyat (BPR) di Salatiga serta menganalisis keabsahan dari perjanjian tersebut. Penelitian ini membahas ketidaksesuaian penerapan perjanjian kredit berdasarkan klausula baku undang- undang No 08 Tahun 1999 tentang perlindungan konsumen. Tujuan penelitian ini adalah untuk memahami proses pelaksanaan dan kendala dari pasal-pasal yang dituangkan dalam perjanjian kredit. Metode penelitian yang digunakan adalah yuridis empiris dengan menggunakan deskriptif analitis. Hasil penelitian dapat disimpulkan bahwa dalam melakukan perjanjian kredit, kreditur tidak melibatkan debitur dalam negosiasi untuk menentukan isi atau pasalpasal perjanjian sehingga klausul yang dibuat merupakan klausul eksonerasi yang telah disusun pada (draft) yang disediakan kreditur kepada notaris dan PPAT untuk disusun sebagai perjanjian yang berbentuk notariil. Perlindungan hukum diberikan dari beberapa sudut pandang yaitu tidak ada negosiasi isi dari perjanjian kredit dan denda dari kelalaian atau keterlambatan pembayaran oleh debitur. Untuk mendapatkan kepastian hukum, kreditur menggunakan gugatan sederhana (small claim court) di Pengadilan Negeri Salatiga untuk menindak tindakan wanprestasi yang dilakukan oleh pihak debitur. Kendala yang dialami kreditur ialah penolakan gugatan yang meminta denda yang dimuat dalam perjanjian berbentuk akta autentik.
\end{abstract}

Kata kunci : Klausula Baku; Perjanjian Kredit; Perlindungan Konsumen. 


\title{
STANDARD CLAUSE IN THE CREDIT CONTRACT OF RURAL BANK
}

\begin{abstract}
This study aims to determine the process and procedures for the preparation of a credit agreement carried out by the Rural Bank Salatiga and to analyze the validity of the agreement. The purpose of this research is to understand and know the implementation of the process and constraints of the articles set forth in the credit agreement, the research method used is empirical juridical. The results of the study can be concluded that in conducting credit agreements, creditors do not involve debtors in negotiations to determine the contents or articles of the agreement so that the clauses created are a clause of exoneration that has been drafted (draft) that has been provided by the creditors given to notary state officials and PPAT to be drafted as a notarial agreement, legal protection is provided from several points of view i.e. the absence of negotiations about the content of the credit agreement. The process carried out by the creditor in the event of problems between the creditor and the debtor is with the realm of litigation of such efforts to obtain legal certainty and the absence of negotiations about fines from negligence or late payment by the debtor. In order to obtain legal certainty, the creditor in determining the default made by the debtor often uses a simple claim court in Salatiga district court, the obstacle experienced by the creditor is if in the lawsuit asks for a fine that is included in the agreement in the form of an authentic deed is unacceptable.
\end{abstract}

Keywords: Default Clauses; Curedit Agreements; Consumer Protection. 


\section{A. PENDAHULUAN}

Revolusi industri 4.0 merupakan perkembangan yang sangat pesat dalam dunia industri untuk meningkatkan perekonomian dan kesejahteraan masyarakat dalam bentuk usaha kecil maupun menengah, sehingga akan diperlukan perhatian dan bantuan dari pemerintah melalui kebijakan yang dibuat pemerintah dalam meningkatkan perekonomian dan kesejahteraan masyarakat salah satunya dengan kebijakan terkait pembiayaan dan pendanaan.. Dampak dari perekonomian suatu usaha merupakan resiko yang timbul akibat dari sebuah pengelolaan bisnis yang tidak baik, bisnis yang tidak baik itu bertumpu kepada manajemen sebuah bisnis yang tidak teliti dan jeli dan terbatasnya finansial dari sebuah pelaku usaha, untuk meningkatkan finansial tersebut perlunya pengembangan perkonomian masyarakat. ${ }^{1}$

Dasar dari perkembangan perekonomian masyarakat tertuju kepada dua sasaran pokok yaitu "kemampuan produksi dan lapangan kerja baru, dalam perkara ini terbentur dengan terbatasnya modal atau sering disebut dengan kredit, hal tersebut disebabkan karena kebutuhan manusia yang sangat tinggi untuk sesuatu yang diinginkan itu terbatas disinilah terjadinya kesenjangan antara kemampuan dengan angan-angan". ${ }^{2}$ Setiap orang atau badan usaha dalam memeunuhi usaha dan kebutuhannya akan memerlukan pembiayaan dalam bentuk kredit mengingat tidak semuanya memiliki modal yang cukup dalam mengembangkan usahanya. ${ }^{3}$

Peran perusahaan yang bergerak dalam bidang jasa finance maupun permodalan untuk mencukupi kebutuhan baik dari segi finansial dari pengusaha makro dan mikro demi meningkatkan produksi, maka disinilah letak dari kegunaan serta fungsi dari bank atau Bank Perkreditan Rakyat (BPR), bank merupakan "badan usaha yang menghimpun dana dari masyarakat dalam bentuk simpanan dan menyalurkannya kepada masyarakat dalam bentuk kredit dan atau bentuk-bentuk lain dalam rangka meningkatkan taraf hidup rakyat banyak". ${ }^{4}$ Bank Perkreditan Rakyat (BPR) atau

\footnotetext{
${ }^{1}$ Efendy Lotulung, "Penegakan Hukum Dalam Era Pembangunan Berkelanjutan", Makalah disampaikan pada Seminar Hukum Nasional ke VIII, yang diselenggrakan di Denpasar, Juli 2003.

2 Muhammad Muaziz, "Pengaturan Klausula Baku Dalam Hukum Perjanjian”, Universitas Diponegoro, 2015

${ }^{3}$ Subekti, “Jaminan-Jaminan Untuk Pemberian Kredit Menurut Hukum Indonesia”, Alumni, Bandung, 1982, hal.41.

${ }^{4}$ Dahlan Siamat, “Manajemen Lembaga Keuangan”, Edisi ketiga Jakarta: Lembaga Penerbit Fakultas Ekonomi Universitas Indonesia, 2001, hal 510.
} 
e-ISSN : 2621-4105

koperasi juga mempunyai persyaratan tertentu dalam kapasitasnya untuk menyediakan bantuan pendaaan maupun pembiayaan bagi para nasabahnya. Persyaratan tersebut termuat dalam perjanjian bersama berupa perjanjian kredit yang disepakati oleh para pihak.Bentuk dari perjanjian kredit tersebut biasanya telah dispersipakan oleh kreditur yang dimaksudkan agar dapat memberikan perlindungan ata pembiayaan yang disalurkan terhadap debitur.Perjanjian kredit yang telah dipersiapkan oleh kreditur tersbut dapat disebut sebagai klausula baku yang ada dalam perjanjian kredit.

Pihak bank selalu kreditur dalam mempersiapkan perjanjian kredit dengan debitur akan menggunkan jasa notaris. Dalam pelaksanaannya pihak bank akan meminta kepada notaris agar memasukan klausula-klausula yang sesuai dengan kehendaknya. Sedangkan notaris dalam menjalankan tugas dan profesinya membuat akta autentik harus mewujudkan kesetaraan/keseimbangan antara kepentingan kreditur dan debitur. ${ }^{5}$

Penelitian sebelumnya yang mengangkat tema tentang klausula baku dalam perjanjian kredit telah diangkat oleh Etty Mulyati (2016) dengan judul "Asas Keseimbangan Pada Perjanjian Kredit Perbankan Dengan Nasabah Pelaku Usaha Kecil" Permasalahan yang diangkat dalam penelitian ini adalah tentang penerapan asas keseimbangan dalam pembuatan perjanjian kredit antara bank sebagai kreditur dengan pelaku usaha kecil sebagai nasabahnya. Penelitian tersebut mengkaji pelaksanaan asas keseimbangan dan adanya iktikad baik dalam perjanjian kredit diantara para pihak. Sedangkan dalam penerapan asas keadilan dan kewajaran pada perjanjian kredit tersebut dilaran klausula tambahan atau klausula yang dibuat secara sepihak oleh kreditur. ${ }^{6}$

Sedangkan penelitian yang dilakukan M. Roji Iskandar (2017) berjudul "Pengaturan Klausula Baku Dalam Undang-Undang Perlindungan Konsumen dan Hukum Perjanjian Syariah", hasil penelitiannya menyimpulkan konsep klausula baku yang disandingkan perspektif hukum syariah dimana dianalisis sesuai dengan prinsip hukum syariah serta diselaraskan dengan Undang-Undang Perlindungan Konsumen yang melarang "setiap aturan atau ketentuan dan syarat-syarat dipersiapkan dan

\footnotetext{
${ }^{5}$ Lina Maulidiana, Rendy Renaldy, Tia Amelia, Ledi Vebriani, "Tanggung Jawab Notaris Terhadap Perjanjian Kredit Bank Dengan Menggunakan Klausula Baku”, Jurnal Hukum Malahayati 1 (1), 2020, hal 76-90.

${ }^{6}$ Etty Mulyati, “Asas Keseimbangan Pada Perjanjian Kredit Perbankan Dengan Nasabah Pelaku”, Jurnal Bina Mulia Hukum 1 (1), 2016, hal 36-42.
} 
ditetapkan terlebih dahulu secara sepihak oleh pelaku usaha yang kemudian dituangkan dalam suatu dokumen dan perjanjian yang mengikat dan wajib dipenuhi oleh konsumen", pencantuman klausula baku bukanlah merupakan keberpihakan terhadap kepentingan konsumen dan merugikan kepentingan pelaku usaha. ${ }^{7}$

Sedangkan penelitian yang dilakukan Mohamad Nur Muliatno Abbas dengan judul "Penyalahgunaan Keadaan Dalam Kontrak Baku Perjanjian Kredit Bank", lebih fokus mengkaji tentang penyalahgunaan keadaan dalam kontrak baku perjanjian kredit. Penelitian ini menjelaskan bahwa adanya klausula baku perjanjian kredit bank terdapat penyalahgunaan keadaan. Hal ini terlihat dari banyaknya klausul perjanjian kredit ynag banyak memberatkan debitur. Adanya ketidakseimbangan posisi antar debitur dengan bank selaku kreditur yang mempunyai keunggulan ekonomi. ${ }^{8}$

Perbedaaan penelitian ini dengan penelitian tentang klausula baku perjenjian kredit pada penelitian ini akan lebih khusus menganalisis tentang klausula baku yang dilakukan kreditur dan debitur dalam pra perjanjian sesuai dengan prosedur yang digunakan serta memberikan batas hukumnya. Berbeda dengan penelitian yang sebelumnya penelitian ini mengacu pada proses transaksi perjanjian antara kreditur dan debitur. Dengan menggunakan bukti perjanjian yang sudah digunakan oleh kedua belah pihak pada saat sebelum transaksi kredit dilakukan sehingga secara tidak langsung konsumen akan lebih terlindungi dalam prosesnya. Bukti perjanjian ini digunakan untuk menganalisis masalah yang dialami antara kreditur dan debitur yang kemudian diselesaikan sesuai dengan ketentuan di BPR Salatiga. Hasil penyeleaiannya akan lebih menguntungkan kedua belah pihak dengan tidak mengesampingkan ketentuan pada bank tersebut.

Dari uraian tersebut penelitian bertujuan untuk menganalisis proses dan prosedur penyusunan perjanjian kredit yang dilakukan oleh BPR di Salatiga, menganalisis keabsahan dari perjanjian kredit tersebut terhadap nasabah sesuai perundang-undangan yang ada. Selain itu juga menganalisis penyelesaian dari pembuat perjanjian kredit yang berklausula baku yang dilakukan BPR Salatiga

\footnotetext{
7 M. Roji Iskandar, Pengaturan Klausula Baku Dalam Undang-Undang Perlindungan Konsumen dan Hukum Perjanjian Syariah, Jurnal Awamluna 1 (2), 2017.

${ }^{8}$ Mohamad Nur Muliatno Abbas, "Penyalahgunaan Keadaan Dalam Kontrak Baku Perjanjian Kredit Bank”, Gorontalo Law Review 3 (2) 2020, hal 188-204. DOI: https://doi.org/10.32662/golrev.v3i2.1162
} 
e-ISSN : 2621-4105

terhadap nasabah sesuai dengan Undang-Undang Nomor 8 Tahun 1999 tentang Perlindungan Konsumen.

\section{B. PERMASALAHAN}

Penelitian ini merumuskan permasalahan tentang bagaimana pelaksanaan dalam pembuatan perjanjian kredit di Bank Perkreditan Rakyat (BPR) Salatiga? Dan bagaimana penerapan klausula baku dalam perjanjian kredit yang diatur? Permaslahan terakhir yang diangkat adalah bagaimana kendala dan solusi dalam perjanjian kredit terhadap penerapan perjanjian dengan klausula baku dalam perjanjian kredit Bank Perkreditan Rakyat (BPR) Salatiga?

\section{METODE PENELITIAN}

Berdasarkan dengan uraian permasalahan, maka penelitian menggunakan metode pendekatan yuridis empirik yang menekankan pada aspek hukum sebagai suatu sikap masyarakat terhadap hukum dan sistem hukum.

Spesifikasi penelitian dalam penelitian ini adalah "deskriptif analitis yang menggambarkan keadaan dari objek yang diteliti dan factor-faktor apa saja yang mempengaruhi data yang diperoleh". 9 Penelitian dikatakan sebagai "penelitian deskriptif karena hasil yang diperoleh dari penelitian ini diharapkan dapat memberikan gambaran menyeluruh dan sistematis mengenai perlindungan hukum terhadap perjanjian kredit dengan klausula baku".

Analis data yang digunakan dilakukan secara kualitatif yang dipadukan dengan metode kuantitaif. Data penelitian diperoleh dengan melakukan pengukuran atas variable yang sedang diteliti. ${ }^{10}$

\section{HASIL DAN PEMBAHASAN}

\section{Pelaksanaan Pembuatan Perjanjian Kredit di Bank Perkreditan Rakyat (BPR) Salatiga}

Kebebasan berkontrak "merupakan "ruh"atau "nafas" dari sebuah perjanjian, yang dilandaskan pada kesadaran bahwa hanya para pihaklah yang mengetahui kebutuhannya untuk melakukan hubungan kontraktual atau perjanjian”. Suatu kontrak perdagangan (bisnis) selalu ada kemungkinan timbulnya konflik atau sengketa yang disebabkan adanya conflict of interest maupun kelalaian salah satu pihak dalam

${ }^{9}$ Soerjono Soekanto dan Sri Mamudji, "Penelitian Hukum Normatif Suatu Tinjauan Singkat”, (Jakarta: Rajawali Press, 1998), hal. 35

${ }^{10}$ H.B. Sutopo, “Metodologi Penelitian Hukum Kualitatif Bagian II',UNS Press, Surakarta, 1998, hal. 37 
memenuhi isi perjanjian. Semakin banyak dan luas jeni kegiatan perdagangan, frekuensi, akan meningkatkan risiko terjandinya sengketa bisni maupun wan prestasi. Konflik akan berkembang menjadi sengketa apabila pihak yang merasa dirugikan menyatakan rasa tidak puas pada pihak yang menimbulkan kerugian pada pihak lain. ${ }^{11}$

Pada praktiknya, dalam membuat dan melaksanakan suatu perjanjian yang melahirkan kontrak (perikatan), sering kali ditemukan permasalahan. Permasalahan dalam kontrak dapat muncul ketika salah satu pihak tidak menjalankan suatu prestasi atau kewajiban sesuai dengan yang disepakati atau adanya perselisihan mengenai makna-makna redaksi dalam kontrak. Permasalahan yang berakar dari dua hal tersebut sering menimbulkan kerugian pada salah satu atau kedua belah pihak. Pada titik inilah terjadi persengketaan antara pihak-pihak yang mengikatkan diri pada kontrak tersebut. $^{12}$

Adanya sengketa ataupun posisi yang tidak seimbang dalam proses perjanjian tidak hanya terjadi dalam perjanjian kredit saja. Suatu perjanjian antara para pihak dengan posisi dominan yang berbeda akan sangan rawan adanya ketidakseimbangan. Sebagai contoh adanya perjanjian kemitraan antara sub kontraktor dan main kontraktor lain. Permasalahan yang terjadi dalam perjanjian kemitraan jenis sub kontraktor yaitu adanya ketidakseimbangan kedudukan diantara para pihak. Permasalahan perjanjian kemitraan lainnya seperti kerja sama operasi (KSO) dalam pelaksanaannya sering timbul adanya ketidakseimbangan dan ketidaksetaraan diantara para pihak di KSO tersebut. Besarnya modal, risiko, kewajiban seringkali tidak sesuai dengan pembagian pekerjaan dan keuntungan. ${ }^{13}$

Penyalahgunaan keadaan sering digunakan oleh pihak bank yang mempunyai posisi lebih tinggi dan unggul memanfaatkan posisi nasabahnya sebagai debitur dalam posisi yang lemah dan butuh adanya uluran dan kreditur. Penyalahgunaan keadaan terjadi manakala "seseorang di dalam suatu perjanjian dipengaruhi oleh suatu

11 Dewi Tuti Muryati, "Pengaturan Dan Mekanisme Penyelesaian Sengketa Nonlitigasi Di Bidang Perdagangan”, Journal Dinamika Sosial Budaya 13 (1) 2011, hal 50.

12 Muhammad Natsir Asnawi, "Perlindungan Hukum Kontrak Dalam PerspektifHukum Kontrak Kontemporer”, Jurnal Masalah-Masalah Hukum 46 (1), 2017. hal 56. DOI:10.14710/mmh.46.1.2017.55-68

13 Zaenal Arifin, Soegianto, Diah Sulistiyani RS, "Perlindungan Hukum Perjanjian Kemitraan PengadaanBarang/Jasa Pemerintah Pada Bidang Konstruksi”, Jurnal USM Law Review 3 (1), 2020, hal 59-76. DOI : $\underline{10.26623 / j u l r . v 3 i 1.2134}$ 
hal yang menghalanginya untuk melakukan penilaian (judgment) yang bebas dari pihak lainya, sehingga tidak dapat mengambil keputusan yang independen". ${ }^{14}$

Bank Perkreditan Rakyat (BPR) adalah "lembaga keuangan bank yang melaksanakan kegiatan usaha secara konvensional atau berdasarkan prinsip syariah yang dalam kegiatannya tidak memberikan jasa dalam lalu lintas pembayaran. BPR hanya melakukan kegiatan berupa simpanan dalam bentuk deposito berjangka, tabungan, dan atau bentuk lainnya yang dipersamakan dan menyalurkan dana sebagai usaha BPR".

Cara untuk meminimalisir kesalahan dalam menjalankan kegiatan usaha dari Perusahaan Daerah Bank Perkreditan Rakyat (BPR) Bank Salatiga untuk membuat perjanjian kredit, Bank Salatiga membuat perjanjian kredit harus terdapatnya sebuah jaminan yang merupakan bagian tidak dapat terpisahkan, dan dapat memberikan hak tanggungan terhadap jaminan yang diberikan notarill/ akta autentik sebagaimana diatur dalam pasal 1868 KUHPerdata yang menjelaskan suatu akta autentik ialah "suatu akta yang dibuat dalam bentuk yang ditentukan undang-undang oleh atau dihadapan pegawai-pegawai umum yang berkuasa untuk itu, di tempat dimana akta itu dibuat". Sehingga debitur dalam hal ini tidak bisa menyangkal dari isi perjanjian serta hak dan tanggung jawab, hal tersebut diatur di pasal 1870 KUHPerdata. Suatu akta autentik memberikan di antara para pihak beserta ahli warisnya atau orang-orang yang mendapat hak dari mereka, suatu bukti yang sempurna tentang apa yang dimuat di dalamnya. ${ }^{15}$

Penyaluran dana berupa pemberian pinjaman kredit kepada masyarakat merupakan kegiatan utama dan menjadi sumber utama pendapatan bank. Kehadiran notaris diperlukan untuk melayani masyarakat yang membutuhkan alat bukti tertulis yang bersifat autentik yang biasa disebut akta, agar perbuatan hukumnya dapat dibuktikan, apabila nanti pada suatu hari ada pihak yang ingkar akan janjinya yang telah diikat dalam suatu perjanjian atau dalam istilah hukum disebut dengan wanprestasi. ${ }^{16}$

${ }^{14}$ Miftah Arifin, "Membangun Konsep Ideal Penerapan Asas Iktikad Baik Dalam Hukum Perjanjian”, Jurnal Ius Constituendum 5 (1), 2020, hal 66-82. DOI : $\underline{\text { 10.26623/jic.v5i1.2119 }}$

${ }^{15}$ Hadi Setia Tunggal, "Undang-Undang Hak Atas Tanah Beserta Benda-Benda Yang Berkaitan Dengan Tanah Dan Perturan Pelaksanaanya", (Jakarta: Harvarindo,2005), hal. 9.

${ }^{16}$ Anissa Nurina Putri, “Kewenangan Notaris Dalam Perjanjian Kredit Dengan Jaminan Fidusia”, Jurnal Hukum Dan Kenotariatan 2 (2), 2018, hal 247-263. DOI: http://dx.doi.org/10.33474/hukeno.v2i2.1508 
Bukti sempurna merupakan hal yang tidak bisa disangkal keberadaan dan isinya dikarenakan notaris telah memastikan bahwa isi para pihak dalam perjanjian memahami isi dari perjanjian dengan cara membacakannya di hadapan para pihak dan memastikan bahwa tanda tangan tersebut sesuai dengan aslinya. Jadi secara tidak langsung pada saat perjanjian dibuat para pihak telah diberi tahu atau dijelaskan mengenai isi perjanjian sebelum ditanda tangani.

Sehingga untuk menjalankan sebuah perjanjian kredit yang dituangkan didalam pasal demi pasal Bank Salatiga telah memiliki draft merupakan klausul/pasal-pasal yang diberikan kepada notaris guna kepentingan dari perbankan sehingga perjanjian tersebut dibuat oleh pejabat negara (notaris).

Praktiknya dalam pemberian perjanjian kredit oleh Bank Salatiga tidak sembarangan debitur yang diberikan melainkan memiliki beberapa kriteria yang harus dipenuhi, sehingga langkah selanjutnya yaitu perikatan/perjanjian tertulis yang berbentuk notaril, kriteria antara lain memiliki sebuah sistem checking yang berisi informasi seluruh penyediaan dana dengan kondisi bermasalah dan lancar. Memiliki usaha yang digunakan untuk memastikan bahwa yang diajukan dalam peminjaman tepat sasaran sehingga tercapai tujuan bak tersebut. Serta memiliki jaminan yang bertujuan untuk menjamin yang diberikan debitur ke kreditur.

Pengajuan permohonan kredit di Bank Perkreditan Rakyat Bank Salatiga oleh debitur kepada bank, syarat dan ketentuan dari Bank Salatiga ditinjau langsung oleh tim survei dari Bank Salatiga, dan melakukan penghitungan asset dengan tim appraisal internal dari bank, apabila syarat dan ketentuan yang telah disepakati oleh kedua belah pihak, maka langkah yang selanjutnya adalah perikatan atau perjanjian.

Perikatan atau perjanjian tersebut dilakukan dengan formulir perjanjian yang disodorkan oleh bank kepada notaris, keterlibatan dari petugas negara, tugas dan fungsi tersebut untuk memberikan/pemasangan hak tanggungan/Akta Pemberian Hak Tanggungan.

Pada dasarnya pemberian hak tanggungan wajib dilakukan oleh pemilik sendiri, hal ini sesuai dengan asas umum yang berlaku bahwa pada dasarnya tindakan hukum harus dilakukan oleh yang berkepentingan sendiri. Namun tidak berarti hal tersebut 
e-ISSN : 2621-4105

tidak dapat disimpangi apabila suatu keadaan yang menghendakinya. Suatu keadaan yang menghendaki bisa dilakukan dikarenakan peraturan memperbolehkan.

Undang-Undang Nomor 4 Tahun 1996 tentang Hak Tanggungan bertujuan memberikan landasan untuk dapat berlakunya lembaga hak tanggungan yang kuat, diantaranya mengenai kedudukan SKMHT, sebagaimana yang disebutkan dalam Pasal 15 Undang-Undang Nomor 4 Tahun 1996 memberikan kesempatan kepada pemberi hak tanggungan untuk menggunakan SKMHT.

Dari persyaratan yang diharuskan untuk pembuatan SKMHT sebagaimana disebutkan dalam Pasal 15 ayat (1) Undang-Undang Nomor 4 Tahun 1996 tersebut diatas, dapat diketahui bahwa pembuatan SKMHT harus dibuat dalam suatu kuasa khusus. Kuasa khusus yang dimaksud adalah apabila pemberi hak tanggungan tidak dapat hadir sendiri di hadapan pejabat yang berwenang. Selain itu substansi SKHMT juga dibatasi yaitu hanya memuat perbuatan hukum yang membebankan hak tanggungan, tidak memuat kuasa untuk menjual, mencantumkan objek secara jelas, nama dan identitas debitor. Sehingga pabila debitor bukan pemberi hak tanggungan jika tidak terpenuhi maka surat kuasa yang bersangkutan batal demi hukum.

Pelaksanaan praktik fidusia, seperti telah dijelaskan bahwa jaminan fidusia memberikan kemudahan bagi para pihak yang menggunakannya, khususnya bagi pemberi fidusia. Namun sebaliknya karena jaminan fidusia tidak didaftarkan, kurang menjamin kepentingan pihak yang menerima fidusia, pemberi fidusia mungkin saja menjaminkan benda yang telah dibebani dengan fidusia kepada pihak lain tanpa sepengetahuan penerima fidusia. ${ }^{17}$

Jaminan yang diberikan kepada kreditur atau Bank Salatiga harus berbentuk Akta Pemberian Hak Tanggungan (APHT) dengan jaminan tanah atau bangunan (benda tidak bergerak), dan apabila motor, mobil atau lainnya (benda bergerak) maka bank salatiga memasang fidusia di Kemenkumham dengan dasar dari perjanjian.

Akta Pemberian Hak Tanggungan (APHT) mengatur persyaratan dan ketentuan mengenai pemberian hak tanggungan dari debitor kepada kreditor sehubungan dengan hutang yang dijaminkan dengan hak tanggungan. Pemberian hak ini dimaksudkan untuk memberikan kedudukan yang diutamakan kepada kreditor yang bersangkutan

${ }^{17}$ Soegianto, Diah Sulistyani R.S, Muhammad Junaidi, “Eksekusi Jaminan Fidusia Dalam Kajian UndangUndang Nomor 42 Tahun 1999 Tentang Jaminan Fidusia”, Jurnal Ius Contituendum 4 (2), 2019, hal 2017-219. DOI : $\underline{10.26623 / \text { jic.v4i2.1658 }}$ 
e-ISSN : 2621-4105

(kreditor preferen) daripada kreditor-kreditor lain (kreditor konkuren). ${ }^{18}$ Sehingga Pemberian Hak Tanggungan adalah "sebagai jaminan pelunasan hutang debitor kepada kreditor sehubungan dengan perjanjian pinjaman/kredit yang bersangkutan”.

Bahwa apabila dengan jaminan benda bergerak PD. BPR Bank Salatiga memasang fidusia. Jaminan Fidusia adalah "hak jaminan atas benda bergerak baik yang berwujud maupun yang tidak berwujud dan benda tidak bergerak khususnya bangunan yang tidak dapat dibebani hak tanggungan sebagaimana dimaksud dalam Undang-Undang Nomor 4 Tahun 1996 tentang Hak Tanggungan yang tetap berada dalam penguasaan pemberi fidusia, sebagai agunan bagi pelunasan utang tertentu, yang memberikan kedudukan yang diutamakan kepada penerima fidusia terhadap kreditor lainnya".

Fidusia yang berarti "penyerahan hak milik atas dasar kepercayaan memberikan kedudukan kepada debitur untuk tetap menguasai barang jaminan, walaupun hanya sebagai peminjam pakai untuk sementara waktu atau tidak lagi sebagai pemilik". Apalagi lembaga fidusia ini dikaitkan dengan ketentuan Pasal 1152 KUHPerdata memang tampaknya sangat bertentangan, karena menurut ketentuan pasal tersebut mengharuskan barang jaminan diserahkan secara fisik kepada pemberi kredit. Ketentuan Pasal 1152 KUH Perdata menyatakan, bahwa : "Jika barang jaminan tetap dibiarkan dikuasai debitur maka jaminan tersebut akan tidak sah". 19

Praktik esksekusi jaminan fidusia, perlu diperhatikan sebenarnya bahwa pada umumnya perusahaan atau lembaga pembiayaan di dalam melaksanakan penjualan atas barang bergerak tersebut kepada konsumen dengan menggunakan perjanjian yang mengikutkan adanya jaminan fidusia bagi objek benda jaminan fidusia berupa Bukti Pemilik Kendaraan Bermotor(BPKB), akan tetapi ternyata dalam prakteknya banyak dari perjanjian yang dibuat oleh perusahaan tersebut tidak dibuat dalam akta notariil (akta notaris) dan tidak didaftarkan di Kantor Pendaftaran Fidusia untuk mendapat sertifikat akta yang memuat irah-irah "Demi Keadilan Berdasarkan Ketuhanan Yang Maha Esa," walaupun secara tertulis lembaga

${ }^{18}$ Pasal 1 ayat (1) Undang-Undang No.4 Tahun 1996 tentang Hak Tanggungan.

${ }^{19}$ Sri Ahyani, "Perlindungan Hukum Bagi Kreditur Pada Perjanjian Jaminan Fidusia", Jurnal Yuridika 24 (1), 2011. 
e-ISSN : 2621-4105

pembiayaan tersebut dalam melakukan perjanjian pembiayaan mencantumkan katakata dijaminkan secara fidusia. ${ }^{20}$

Sehingga apabila terjadi permasalahan antara kreditur dengan debitur tentang jaminan bergerak yang telah didaftarkan fidusia, sebagaimana diatur dalam pasal 35 Undang-undang No 42 Tahun 1999 yang berbunyi “Setiap orang yang dengan sengaja memalsukan, mengubah, menghilangkan atau dengan cara apapun memberikan keterangan secara menyesatkan, yang jika hal tersebut diketahui oleh salah satu pihak tidak melahirkan perjanjian Jaminan Fidusia, dipidana dengan pidana penjara paling singkat 1 (satu) tahun dan paling lama 5 (lima) tahun dan denda paling sedikit Rp.10.000.000,-(sepuluh juta rupiah) dan paling banyak Rp.100.000.000,- (seratus juta rupiah)".

\section{Penerapan Klausula Baku Dalam Perjanjian Kredit Yang Diatur di Bank Perkreditan Rakyat (BPR) Salatiga}

Pada pelaksanaannya lembaga pembiayaan menyediakan "barang bergerak yang diminta konsumen kemudian diatasnamakan konsumen sebagai debitur (penerima kredit/pinjaman)". Konsekuensinya debitur menyerahkan kepada kreditur(pemberi kredit) secara fidusia. Artinya, debitur sebagai pemilik atas nama barang menjadi pemberi fidusia kepada kreditur yang dalam posisi sebagai penerima fidusia. Praktik sederhana dalam jaminan fidusia adalah “debitur/pihak yang punya barang mengajukan pembiayaan kepada kreditor, lalu kedua belah sama-sama sepakat mengunakan jaminan fidusia terhadap benda milik debitur". ${ }^{21}$

PD. BPR Bank Salatiga telah memberikan formulir sebagai pra-perjanjian, sehingga apabila nasabah atau debitur tersebut setuju dengan bunga yang diberikan kepada pihak BPR Bank Salatiga maka selanjutnya akan dilakukannya perjanjian, perjanjian tersebut merupakan perjanjian baku, yang dihadapkan di hadapan pejabat negara (notaris) sehingga perjanjian tersebut merupakan perjanjian notarial.

Perjanjian baku merupakan konsep janji-janji tertulis. Disusun tanpa membicarakan isinya dan lazimnya dituangkan ke dalam sejumlah tak terbatas perjanjian yang sifatnya tertentu. Perjanjian baku juga merupakan perjanjian yang

${ }^{20}$ Alfian, “Eksekusi Objek Jaminan Fidusia Dalam Kontrak Pembiayaan Konsumen Di Kota Palu”, Jurnal Katalogis 5 (1), 2017, hal 14.

${ }^{21}$ Fandy Ahmad, "Keabsahan Kuasa Untuk Menandatangani Akta Oleh Lembaga Pembiayaan Jaminan Fidusia Suatu Kajian Peraturan Pemerintah Nomor 21 Tahun 2015”, Jurnal Ius Constituendum 3 (2), 2018, hal 147-165. DOI : $\underline{10.26623 / j i c . v 3 i 2.1037}$ 
e-ISSN : 2621-4105

isinya dibakukan dan dituangkan dalam bentuk formulir dalam praktinya nasabah tidak diikutkan dalam pembuatan perjanjian dalam menentukan pasal-pasal yang dimuat sehingga tidak adanya negosiasi yang seimbang antara debitur dengan kreditur.

Sebagaimana dijelaskan oleh Prof. Fauzie Hasibuan dalam sidang terbuka "Jika keseimbangan proses negosiasi tidak dapat diwujudkan, maka kontrak tersebut tidak memberikan keadilan."22

Sesuai dengan Pasal 1 ayat (10) Undang-Undang Nomor 8 Tahun 1999 tentang Klausula baku, maka perjanjian baku yang banyak terdapat di lingkungan masyarakat dapat dibedakan menjadi 3 yakni perjanjian baku sepihak yang sisinya ditentukan oleh pihak yang kuat kedudukannya di dalam perjanjian tersebut. Perjanjian baku yang ditetapkan oleh pemerintah sisinya ditentukan pemerintah terhadap perbuatan hukum tertentu, serta perjanjian baku di lingkungan notaris dan advokat yang konsepnya sudah disediakan.

Penerapan klausula baku juga diatur dalam undang-undang perlindungan konsumen nomer 8 Tahun 1999, pada pasal 18 dengan ketentuan memberi hak kepada pelaku usaha untuk mengurangi manfaat jasa atau mengurangi harta kekayaan konsumen yang menjadi obyek jual beli jasa (pasal 18 huruf f) dan Pelaku usaha dilarang mencantumkan klausula baku yang letak atau bentuknya sulit terlihat atau tidak dapat dibaca secara jelas, atau yang pengungkapannya sulit dimengerti (pasal 18 ayat 2).

Dalam pasal 18 Undang-Undang Nomor 8 Tahun 1999 tentang Perlindungan Konsumen menggunakan istilah "klausula baku adalah "setiap aturan atau ketentuan dan syarat-syarat yang telah dipersiapkan dan ditetapkan terlebih dahulu secara sepihak oleh pelaku usaha yang dituangkan dalam suatu dokumen dan/atau perjanjian yang mengikat dan wajib dipenuhi oleh konsumen".

PD. BPR Bank Salatiga dalam melaksanakan perjanjian kredit tersebut, bank telah memiliki draft yang diajukan oleh notaris untuk menentukan dari perjanjian yang berbentuk notarial dari segala perjanjian pembiayayaan, dan bank juga telah memiliki platform dalam pengambilan pinjaman beserta jangka waktu yang telah ditetapkan oleh bank, bahwa ketika pengajuan kredit telah mendapatkan persetujuan dan diterima

22 Diakses dari : https://www.hukumonline.com/berita/baca/lt5dcd33a841285/prof-fauzie-hasibuan-penerapan-asas-kebebasan-berkontrak-di-indonesia-harus-menekankan-keadilan/ pada tanggal 1 November 2020, pukul 21:13. 
maka prosedur selanjutnya ialah tanda tangan perjanjian serta pemasangan APHT maupun fidusia.

Berdasarkan teori kepastian hukum, sifat umum dari aturan-aturan hukum membuktikan bahwa hukum tidak bertujuan untuk mewujudkan keadilan atau kemanfaatan, melainkan semata-mata untuk kepastian. ${ }^{23}$ Adanya kepastian hukum merupakan harapan bagi para pencari keadilan terhadap tindakan sewenang-wenang dari aparat penegak hukum yang terkadang selalu bersikap arogan dalam menjalankan tugasnya sebagai penegak hukum. Oleh karena itu, dengan adanya kepastian hukum masyarakat akan mengetahui kejelasan mengenai hak dan kewajiban menurut hukum. Tanpa adanya teori kepastian hukum, maka seseorang tidak akan tahu apa yang harus diperbuat. kepastian hukum ini dapat diwujudkan melalui suatu undang-undang yang jelas bagaimana ketentuan dan penerapannya.

Berdasarkan teori keadilan yang dikemukakan oleh Gustav Radburch dalam hukum terdapat 3 (tiga) pilar utama, yaitu kemanfaatan, keadilan dan kepastian hukum. Dalam kaitannya dengan pelaksanaan perlindungan hukum terhadap nasabah/debitur yang melakukan wanprestasi akibat terjadinya tingkat usaha yang tidak stabil dan merasa terbebani oleh perjanjian dalam hal ini merupakan denda atas tunggakan yang dilakukan debitur sudah tergolong dalam asas-asas perlindungan konsumen. Asas-asas tersebut sudah dilaksanakan oleh kreditur sebagai upaya untuk memberikan kemanfaatan, keadilan, dan kepastian hukum untuk nasabah dikarenakan PD. BPR Bank Salatiga .melakukan proses hukum sebagaimana mestinya. Sedangkan, untuk teori kepastian hukum dalam pelaksanaannya masih tergolong telah memenuhi peraturan perundang-undangan yang berlaku, hal ini dikarenakan kreditur dalam hal ini PD. BPR Bank Salatiga telah menjalankan proses dari perjanjian sebagaimana mestinya sehingga tidak adanya kekeliruan didalam proses pra-perjanjian, perjanjian hingga ranah litigasi.

Dalam teori perlindungan hukum terdapat 2 (dua) bentuk perlindungan, yaitu secara preventif dan represif. Perlindungan hukum secara preventif yaitu tidak memberikan kesempatan terhadap debitur dalam melakukan negosiasi terhadap perjanjian sehingga apabila terjadinya sebuah sengketa litigasi, dalam masih belum memenuhi kriteria tersebut. Sedangkan, perlindungan hukum secara represif yaitu

${ }^{23}$ Riduan Syahrani, “Rangkuman Intisari Ilmu Hukum”, (Bandung: Citra Aditya, 1999), hlm. 23. 
e-ISSN : 2621-4105

Kreditur/ pihak PD. BPR Bank Salatiga selalu membawa permasalahan tersebut ke jalur litigasi.

\section{Kendala dan Solusi Penerapan Perjanjian Klausula Baku Dalam Perjanjian Kredit Bank Perkreditan Rakyat (BPR) Salatiga}

Kendala dalam perjanjian kredit terletak pada ketidakseimbangan kedudukan, ini dapat terlihat dari bentuk perjanjian kredit itu sendiri yang telah dipersiapkan sedemikian rupa sehingga nasabah debitur hanya perlu membaca dan menandatangani perjanjian tersebut. Lantaran perjanjian kredit bank umumnya berupa perjanjian baku, pihak bank cenderung hanya memperhatikan kepentingan-kepentingan bank saja dalam menentukan hak dan kewajiban pada pihak debitur/ nasabah. sehingga hal ini menimbulkan pandangan bahwa bank kurang memperhatikan kepentingan nasabah debiturnya.

Perjanjian yang dilakukan oleh PD. BPR Bank Salatiga tidak melibatkan notaris sebagai pejabat negara, sehingga perjanjian tersebut bukan berbentuk perjanjian notariil dan jaminan yang diberikan terhadap PD. BPR Bank Salatiga menyediakan hak tanggungan (APHT).

Kendala pada perjanjian pasal 8 perjanjian kredit dari PD. BPR Bank Salatiga penolakan gugatan denda keterlambatan pembayaran melebihi jatuh tempo kredit. Jika peminjam tidak melunasi hutangnya, maka peminjam diwajibkan untuk melakukan pembayaran tambahan (denda) dimana dalam ranah litigasi hal tersebut tidak dapat dikabulkan dengan pertimbang-pertimbangan yang sulit untuk dibuktikan.

Ranah litigasi yang ditempuh oleh PD. BPR Bank Salatiga untuk menyelesaikan wanprestasi adalah gugatan sederhana (GS) untuk kredit diatas 500 juta sebagaimana diatur dalam peraturan mahkamah agung (PERMA) No. 2 Tahun 2015.

Gugatan sederhana merupakan pemendekan/ pemotongan proses dari gugatan biasa, dalam gugatan sederhana tidak terdapat replik, duplik maupun kesimpulan dengan jarak atau waktu sidang selama 25 Hari. diharuskan 1 (satu) domisili yang sama, dan tidak memiliki upaya hukum lainnya. Hanya memiliki upaya hukum keberatan.

Pasal dari perjanjian mencantumkan denda serta bunga yang diberikan nasabah kepada PD. BPR Bank Salatiga. sebagaimana putusan yang telah ditetapkan dan telah 
e-ISSN : 2621-4105

berkekuatan hukum ( inkrach van gewijde) dalam perkara no 2/ Pdt. G.S/ 2020/ PN. Slt. PD BPR Bank Salatiga dalam posita mencantumkan beberapa hal yang perlu digaris bawahi, diantaranya adalah :

a. Membahas objek yang menjadi jaminan dalam perjanjian.

Yaitu setifikat tanah milik Tergugat II sebagai penjamin, berupa SHM (Sertifikat Hak Milik) No. 01574 yang telah mendapatkan Akta Pemberian Hak Tanggungan (APHT) dari Notaris/PPAT Supriyadi, S.H Nomor 219/2017 tanggal 18 Mei 2017.

b. Mencantumkan denda, bunga, kerugian immateriil atau tunggakan pokok.

Bahwa didalam mencantumkan bunga, denda serta kerugian immateriil serta pokok sejumlah Rp. 439.674.098,- dengan nilai pokok yaitu sebesar Rp. 300.000.000,yang menjadi tuntutan dari PD. BPR Bank Salatiga.

c. Putusan yang terdapat.

Bahwa dalam putusan no 2/ Pdt. G.S/ 2020/ PN. Slt sebagaimana posita dan petitum yang di mintakan oleh PD. BPR Bank Salatiga yang dikabulkan oleh hakim hanyalah pokok dari hutang dengan pertimbangan sebagai berikut :

"menimbang bahwa oleh karena tidak terdapat bukti yang cukup untuk dipertimbangkan terkait bunga dan denda berikut tunggakan bulanan berjalan, maka hakim berpendapat terhadap nilai kerugian materiil yang dialami penggugat tidak akan dipertimbangkan dan sudah sepatutnya ditolak"

Dari penjabaran diatas merupakan suatu bukti bahwa pasal yang terdapat di perjanjian kredit Bank Salatiga yang merupakan bentuk keuntungan yang seharusnya diperoleh oleh korporasi atau Bank Salatiga belum tentu dikabulkan dan dapat diterima oleh hakim/ pengadilan sebagai pertimbangan, walau dalam pasal tersebut merupakan klausul baku yang digunakan oleh salah satu pihak.

\section{E. PENUTUP}

Perjanjian yang dilakukan oleh PD. BPR Bank Salatiga tidak melibatkan Notaris sebagai pejabat negara, sehingga perjanjian tersebut bukan berbentuk perjanjian notariil dan jaminan yang diberikan terhadap PD. BPR Bank Salatiga menyediakan hak tanggungan (APHT). Perjanjian yang dibuat oleh pejabat negara (notaris) merupakan sebuah akta autentik maupun notarial yang didalamnya terdapat Akta Pemberian Hak Tanggungan sehingga perjanjian itu tidak dapat disangkal oleh pihak 
e-ISSN : 2621-4105

yang terikat, dan merupakan alat bukti yang sempurna, serta klausul/ pasal-pasal yang telah disepakati oleh kedua belah pihak, dalam praktiknya PD. BPR Bank Salatiga tidak semua yang diberikan pembiayaan berbentuk notarial sehingga solusi yang dilakukan Kreditur ialah melakukan perjanjian ulang (addendum) dengan memberi waktu pembayaran yang lebih longgar serta perjanjian ulang tersebut berbentuk notarial, apabila dalam debitur melakukan pembiayaan yang macet (wanprestasi) terhadap perjanjian tersebut, maka langkah yang dilakukan PD. BPR Bank Salatiga melakukan gugatan di pengadilan negeri salatiga (sesuai dengan kompetensi relatif dalam perjanjian), dan pembiayaan yang diberikan kurang dari 500 juta akan diajukannya gugatan sederhana (small claim court) sebagaimana diatur di peraturan mahkamah agung (PERMA) No. 2 Tahun 2015, kendala yang dialami oleh kreditur adalah pasal 8 dalam perjanjian kredit yang meminta bunga maupun denda keterlambatan yang jarang dikabulkan oleh majelis hakim.

\section{DAFTAR PUSTAKA}

\section{Buku}

Dahlan Siamat, "Manajemen Lembaga Keuangan", Lembaga Penerbit Fakultas Ekonomi Universitas Indonesia, Jakarta, 2001.

H.B. Sutopo, “Metodologi Penelitian Hukum Kualitatif Bagian II',UNS Press, Surakarta, 1998.

Hadi Setia Tunggal, "Undang-Undang Hak Atas Tanah Beserta Benda-Benda Yang Berkaitan Dengan Tanah Dan Perturan Pelaksanaanya”, Jakarta: Harvarindo, 2005.

J. Satrio, "Hukum Perikatan yang Lahir dari Perjanjian", PT. Citra Aditya Bakti, Bandung, 1995.

Muhammad Muaziz, "Pengaturan Klausula Baku Dalam Hukum Perjanjian", Universitas Diponegoro, Semarang, 2015.

Riduan Syahrani, “Rangkuman Intisari Ilmu Hukum”, Bandung: Citra Aditya, 1999. Soerjono Soekanto, Sri Mamudji, "Penelitian Hukum Normatif Suatu Tinjauan Singkat”, Rajawali Press, Jakarta, 1998.

Subekti, "Jaminan-Jaminan Untuk Pemberian Kredit Menurut Hukum Indonesia", Alumni, Bandung, 1982.

\section{Jurnal}

Alfian, "Eksekusi Objek Jaminan Fidusia Dalam Kontrak Pembiayaan Konsumen Di Kota Palu”, Jurnal Katalogis 5 (1), 2017. 
Anissa Nurina Putri, "Kewenangan Notaris Dalam Perjanjian Kredit Dengan Jaminan Fidusia”, Jurnal Hukum Dan Kenotariatan 2 (2), 2018. DOI: http://dx.doi.org/10.33474/hukeno.v2i2.1508

Dewi Tuti Muryati, "Pengaturan Dan Mekanisme Penyelesaian Sengketa Nonlitigasi Di Bidang Perdagangan”, Journal Dinamika Sosial Budaya 13 (1) 201.

Etty Mulyati, "Asas Keseimbangan Pada Perjanjian Kredit Perbankan Dengan Nasabah Pelaku”, Jurnal Bina Mulia Hukum 1 (1), 2016.

Fandy Ahmad, "Keabsahan Kuasa Untuk Menandatangani Akta Oleh Lembaga Pembiayaan Jaminan Fidusia Suatu Kajian Peraturan Pemerintah Nomor 21 Tahun 2015", Jurnal Ius Constituendum 3 (2), 2018. DOI : 10.26623/jic.v3i2.1037

Lina Maulidiana, Rendy Renaldy, Tia Amelia, Ledi Vebriani, "Tanggung Jawab Notaris Terhadap Perjanjian Kredit Bank Dengan Menggunakan Klausula Baku”, Jurnal Hukum Malahayati 1 (1), 2020.

Muhammad Natsir Asnawi, "Perlindungan Hukum Kontrak Dalam PerspektifHukum Kontrak Kontemporer”, Jurnal Masalah-Masalah Hukum 46 (1), 2017.

DOI:10.14710/mmh.46.1.2017

Mohamad Nur Muliatno Abbas, "Penyalahgunaan Keadaan Dalam Kontrak Baku Perjanjian Kredit Bank”, Gorontalo Law Review 3 (2) 2020, hal 188-204. DOI: https://doi.org/10.32662/golrev.v3i2.1162

Miftah Arifin, "Membangun Konsep Ideal Penerapan Asas Iktikad Baik Dalam Hukum Perjanjian”, Jurnal Ius Constituendum 5 (1), 2020. DOI : 10.26623/jic.v5i1.2119

M. Roji Iskandar, Pengaturan Klausula Baku Dalam Undang-Undang Perlindungan Konsumen dan Hukum Perjanjian Syariah, Awamluna 1 (2), 2017.

Soegianto, Diah Sulistyani R.S, Muhammad Junaidi, "Eksekusi Jaminan Fidusia Dalam Kajian Undang-Undang Nomor 42 Tahun 1999 Tentang Jaminan Fidusia", Jurnal Ius Contituendum 4 (2), 2019. DOI : 10.26623/jic.v4i2.1658

Sri Ahyani, "Perlindungan Hukum Bagi Kreditur Pada Perjanjian Jaminan Fidusia", Jurnal Yuridika 24 (1), 2011.

Zaenal Arifin, Soegianto, Diah Sulistiyani RS, "Perlindungan Hukum Perjanjian Kemitraan PengadaanBarang/Jasa Pemerintah Pada Bidang Konstruksi”, Jurnal USM Law Review 3 (1), 2020. DOI : 10.26623/julr.v3i1.2134

\section{Peraturan Perundang-undangan}

Kitab Undang-Undang Hukum Perdata

Undang-Undang No. 8 Tahun 1999 tentang Perlindungan Konsumen

Undang-undang Nomor 7 Tahun. 1992 tentang Perbankan

\section{Internet}

Pengertian Perlindungan Hukum Menurut Para Ahli, http://tesishukum.com.

Fence M. Wantu, Artikel Kreditur, https://jurnal.ugm.ac.id/jmh/article/view/19070 